\title{
$\bullet$ \\ Nomophobic Rate and Social Media Usage of Higher Secondary Students
}

IJCRR

Section: Healthcare

ISI Impact Factor

(2019-20): 1.628

IC Value (2019): 90.81

$\operatorname{SJIF}(2020)=7.893$

(c) (i) (8)

Copyright@IJCRR

\section{Jijish Elias ${ }^{1}$, M Mirunalini², Issac Paul}

\author{
'Research Scholar, Department of Educational Technology, Bharathidasan University, India; ${ }^{2}$ Research Supervisor and Assistant Professor, Depart- \\ ment of Educational Technology, Bharathidasan University, India; ${ }^{2}$ Research Co-supervisor and Assistant Professor, Govt. College of Teacher \\ Education, Thiruvananthapuram, India.
}

\section{ABSTRACT}

Introduction: Adolescents' usage of mobile phones and social media has increased as a consequence of the Covid-19 restriction. They develop an increased reliance on mobile phones and social media as a consequence of their educational and recreational uses. In this context, it is critical to examine the connection between social media usage and the nomophobic rate among teenagers.

Aim: The researchers sought to create a social media usage scale (SMUS) and nomophobic rating scale (NMPRS) that students and teachers at the higher secondary level could use to assess their social media usage and nomophobic rate.

Methods: A nomophobic rating scale and social media usage scale developed and validated by the investigators used to identify the nomophobic prevalence and extent of social media usage among higher secondary students. The study conducted among 1068 higher secondary students and the evaluation of collected data helped to draw conclusions and Nomophobic rating.

Results: The data analysis followed by interpretation blow light to the fact that most of the higher secondary students show prevalence towards social media. It is also concluded that the higher secondary students are less prevalent to nomophobia. The gender and locality of students do not show an influence on their social media usage and nomophobic rate. But school management plays a role in the nomophobic rate. Government school students differ from aided and un-aided school students in nomophobic rates. The correlation analysis reveals that the nomophobic rate is positively correlated with social media usage.

Conclusion: This research raises major issues about the need for adequate supervision of adolescent mobile phone usage. It also emphasizes the importance of timely interventions from teachers, parents, and professionals, which will invariably improve kids' physical, social, and emotional development in higher secondary school. So the investigators suggest the society take precautions to check their wards from getting addicted to gadgets.

Key Words: Higher secondary students, Nomophobia, Nomophobic rate, Social media, Social media usage, Smartphone addiction

\section{INTRODUCTION}

Substantial advances happened around the world in recent years, particularly in terms of the quantitative and qualitative expansion of the internet, social networks, and the number of individuals who utilise these technologies. Social media applications are contemporary technological breakthroughs that aim to improve communication and collaboration on a wider scale than previously possible. ${ }^{1}$ Social media has become the part and parcel of every individual's life and has an impact on both their personal and professional lives. Social media were integrated into people's social lives in an astonishingly short period of time and spread to their daily activities at an even faster rate.
Social media is a word that refers to a collection of tools that include blogging, discussion forums, social networking sites, wikis, and other similar platforms. However, the majority of people use the term "social media" to refer to social networking sites only. Social media can be defined as "a group of Internet-based applications that build on the ideological and technological foundations of Web 2.0, and that allow the creation and exchange of User Generated Content". ${ }^{2}$ As a critical communicational route and a source of social support, social media play a significant role in educational contexts.

Online social media allows users to stay in touch with old friends, reconnect with old friends, and make new real-life

\section{Corresponding Author:}

Jijish Elias, Research Scholar, Department of Educational Technology, Bharathidasan University, India. Email:mph15jijish@gmail.com

ISSN: 2231-2196 (Print)

Received: 02.11 .2021
ISSN: 0975-5241 (Online)

Revised: 23.11 .2021
Accepted: 02.12 .2021
Published: 13.12 .2021 
acquaintances. Online social networks have made it easier for communities to keep in touch with old friends and create new ones. ${ }^{3}$ Joining clubs or forums allow users to exchange interests and ideas with others who share their interests. They can also participate in online conversations via social media. They help members of networked groups learn more and create more information. These days, personal and professional information is exchanged via online social networking sites like Facebook, WhatsApp, Twitter, etc. Various user communities currently use online social networks for a variety of purposes ranging from light-hearted banter to serious research. The internet is a great place to share knowledge and communicate.

With the outbreak of the pandemic, the use of technology, especially smartphones, has increased in almost every facet of daily life. It has had a significant impact on both the teaching and learning process. Teaching and learning practices have shifted to online platforms dramatically in the COVID-19 context. Smartphones and social media are now being used extensively in academic activities by both students and faculty, and their use is becoming increasingly important. Even prior to the widespread of COVID-19, teenage students expressed a strong desire for new devices such as mobile phones for playing video games and interacting with various social media applications, such as Facebook and WhatsApp. As a result of the pandemic crisis, students and adolescents have increased their use of social media both for recreational and instructional objectives.

In this regard, the use of social media by adolescents and the nomophobic rate them is a research topic that requires further investigation, particularly in the case of problematic use. ${ }^{4}$ Similarly, according to studies, social media applications are the most frequently used applications on smartphones. ${ }^{5}$ NOMOPHOBIA, also known as NO Mobile Phone PhoBIA, is a phrase used to describe a specific psychological ailment in which people are afraid of being cut off from their mobile phone's internet connection. Nomophobia has evolved into a psychosocial condition in recent years, owing to the fact that the socialisation process is carried out through social media, and since the majority of people have access to social media through their smartphones.

\section{REVIEW OF RELATED LITERATURE}

According to Jose, M., Tomy, L. \& Chesneau, C. (2021), social media has given everyone a new level of awareness and opportunity. They are fast gaining popularity among the younger generations worldwide. Social media is heavily used by late teens and early twenties. ${ }^{6}$ Saini et al. (2020) sought to examine how time spent on social networking sites affects overall quality of life, particularly among college students. The study found that almost all respondents use the Internet. The study found that social media greatly influenced youngsters in India. ${ }^{7}$

Tutgun Ünal, A (2020) studied the social networking addiction of Üsküdar University students who were avid gadget users. This quantitative investigation found that students were more addicted to social media. ${ }^{8}$ Barnes, S., Pressey, A. \& Scornavacca, E. (2019) conducted a study on business students in the Mid-Atlantic region of the United States. The study results revealed that the usage of smartphones and social networking sites changes with the academic needs and academic level of samples. The samples which were addicted to smartphones had higher cognitive adsorption, and their social media usage rate was also higher. ${ }^{9}$

Olmsted, S. \& Xiao, M.(2019) analysed the relationship between smartphone dependency and usage of media, including smart media and social media. The study results revealed that there was a positive correlation between the usage of smartphones with social media usage. ${ }^{10}$

Ayar, D., Özalp Gerçeker, G., Özdemir, E. \& Bektaş, M. (2018) investigated the effect of Internet usage, social media usage and nomophobia levels among 755 nursing students. After analysing the reports, the researcher concluded that all the variables were positively correlated. So they concluded that there was a higher positive correlation between social media usage and nomophobic rate among the nursing students. ${ }^{11}$

Yılmaz, R., Karaoğlan Yılmaz, F., Öztürk, H. \& Karademir, T. (2018) conducted a study with 514 secondary school students using a relational screening model. It was discovered that students have a low degree of nomophobia and that there was a substantial negative link between nomophobia and the use of social media sites. In contrast to the use of social networks for entertainment, it has been discovered that there was a negative but higher link between social network use for study, collaboration, initiating contact, communication, maintaining communication, and content sharing and the tendency to nomophobia. ${ }^{12}$

Salehan, M \& Negahban, A. (2013) investigated the impact of smartphone usage on social media usage. The study results reported that the rate of social networking sites could be directly correlated with the nomophobic rate. All samples which were using the social networking sites showed a positive correlation with their nomophobic rate. ${ }^{13}$

\section{NEED AND SIGNIFICANCE OF THE STUDY}

According to a study of related literature, multiple studies in the field of social media users have been undertaken by various researchers at various levels, with the majority of the studies being carried out among undergraduate and medical students in particular. One thing that was missing from the 
research, particularly those from India, was any information on the usage of cell phones and social media by secondary or higher secondary students. The lack of access to a cell phone was the most significant factor in avoiding studies including that age range. But when the pandemic scenario caused the establishment of an academic environment in which a cell phone was required, the vast majority of parents were compelled to purchase one for their children. The research is being carried out one year after the first COVID -19 instance was identified in the globe, and as a result, it is very relevant to the current scenario of the pandemic. A study on social media use and the nomophobic rate among higher secondary students, as a result, is urgently needed, according to the experts.

\section{OBJECTIVES OF THE STUDY}

In the current study, the general objective is to identify the extent social media usage and extent of nomophobic rate among higher secondary students.

Along with the general objective, the following are the specific objectives.

1. Identify the extent of nomophobic rate among higher secondary students.

2. Identify the extent of social media usage among higher secondary students.

3. Identify how demographic factors related to nomophobic rate and social media usage among higher secondary students.

4. To identify the relationship between extent of nomophobic rate and social media usage among higher secondary students

\section{Hypotheses}

The following hypotheses were developed by the investigators and tested for significance to generalize the conclusions.

1. Higher secondary students have a high extent of nomophobic rate.

2. Higher secondary students have a high extent of social media usage.

3. Higher secondary students show no significant difference in terms of their gender, locality and management of schools in relation to nomophobic rate and social media usage.

4. Higher secondary students show no significant association between their nomophobic rate and social media usage.

\section{METHODS}

\section{RESEARCH DESIGN}

For the current analysis, the researchers used a descriptive research design. The study was executed in the Kerala state of India. Three districts one from the south, one from central and one from north of Kerala were selected for sample selection. Adequate priority was given to Government, Aided and Unaided schools and a total of 1068 samples were selected. Students studying in the second year of higher secondary courses in three different streams were comprised as the participants in this research.

\section{INSTRUMENT OF THE STUDY}

The investigators used a social media usage scale and nomophobic rating scale that was constructed and standardized for this study.

The Social Media Usage Scale for higher secondary students (SMUS) was a three-stage Likert scale with a 5-point scale containing 22 items with 10 negative statements. For a good scale, Cronbach's alpha coefficient value should be higher than 0.7 and in this scale, it is 0.841 . This value shows that the scale is reliable. The validity of the scale is established using the square root of alpha method. The square root of reliability coefficient is 0.917 for the SMUS and thus the intrinsic validity for the SMUS is established. ${ }^{14}$

The Nomophobic rating scale for higher secondary students (NMPRS) was a 5 point Likert scale containing 24 items among them 18 items are positively polar and the rest are negatively polar items. ${ }^{16}$ Cronbach's Alpha test gives an alpha value of 0.812 which shows that the scale is highly reliable. Each item in the final scale was selected according to the norms given by Louis Edwards, A. (1983), ie as per the $t$ values. So the item validity of the scale is established. ${ }^{15}$

\section{DATA COLLECTION AND DATA ANALYSIS}

The investigator encoded SMUS and NMPRS into Google form and shared it with higher secondary students in various streams of study in different schools via WhatsApp groups of their respective schools, and 1068 responses were collected using Google form as a Google sheet. The responses collected from higher secondary students were converted into scores as per the scoring key for each scale. The scoring procedure and types of items is given in table 1 . The scale's total score is the sum of all the items' ratings.

\section{Table 1: Responses and Scores for different items in NMPRS and SMUS}

\begin{tabular}{lcc} 
Response & \multicolumn{2}{c}{ Score } \\
& Positive Item & Negative Item \\
\hline Strongly agree (SA) & 5 & 1 \\
Agree (A) & 4 & 2 \\
Undecided (U) & 3 & 3 \\
Disagree (D) & 2 & 4 \\
Strongly Disagree (SD) & 1 & 5 \\
\hline
\end{tabular}


To compare the means of social media usage and nomophobic rate concerning demographic variables, namely, gender and students' location, the investigator used the students t' test. For the school management, ANOVA was used to compare means.

The significance of the difference in mean values of social media usage and nomophobic rate with respect to gender, student locality, and school management were determined using the t-test. mean value of the nomophobic rate of higher secondary students was 67.81 with a standard deviation of 12.78 in the nomophobic rating scale. In the nomophobic rating scale, there are 24 items on a five-point scale. So the minimum score would be 24 and the maximum score would be 120 with a mid-value 72 . The mean value of a score lower than 69 (median) indicates the higher secondary students were less prevalent to nomophobia. the mean value of social media usage score of higher secondary students was 62.28 with a standard deviation of 8.447 on the social media scale. In this rating scale, there are 22 items on a five-point scale. So the minimum score would be 22 and the maximum score would be 110 with a mid-value 66 . The mean value of a score slightly higher than 62 (median) indicates that higher secondary students were slightly prevalent in social media usage. So hypothesis 1 is rejected and hypothesis 2 is accepted.

The ethical clearance number for this study was No. 16872/Ph D K7/ Education/part Time January 2018 dated 28.12.2017.

Table 2 shows that the 't' values for Nomophobic rate (0.808) and Social media usage (0.229) at a level of sig- nificance 0.05 were lower than the table value. Hence it can be concluded that the Nomophobic rate and Social media usage of higher secondary students do not differ significantly with respect to their gender. Hypothesis 3 is so accepted.

Table 3 shows that the ' $t$ ' values for Nomophobic rate (0.811) and Social media usage (1.280) at a level of significance 0.05 were lower than the table value. Hence it can be concluded that the Nomophobic rate, Social intelligence and Social media usage of higher secondary students do not differ significantly with respect to their locality. Hypothesis 4 is so accepted.

It is observed from Table 4 that the obtained $\mathrm{F}$ value for Nomophobic rate $(3.532)$ is greater than the table value at 0.05 level of significance. Hence the null hypothesis is rejected which means higher secondary students from at least some of the school management have significant differences with respect to nomophobic rate. F value of social media usage (1.073) is less than the table value (3.004) at a 0.05 level of significance. This means that there is no significant difference between higher secondary students from government, aided and unaided schools with respect to their social media usage. So hypothesis 5 is rejected.

In order to make further comparisons among the groups, Fisher's Least Significant Difference Test (LSD) is employed which helped to compare the mean scores of government school students with aided and unaided school students and vice versa with respect to their Nomophobic rate.

Table 2: Significance of difference between mean scores of Nomophobic rate and Social media usage of higher secondary students in relation to their gender

\begin{tabular}{llcccccc} 
Variable & Gender & N & Mean & SD & t & df & Sig. \\
Nomophobic rate & Female & 782 & 67.61 & 12.69 & \multirow{2}{*}{0.808} & \multirow{2}{*}{1066} & 0.419 \\
& Male & 286 & 68.32 & 13.08 & & & \\
Social media usage & Female & 782 & 62.31 & 8.48 & \multirow{2}{*}{0.229} & \multirow{2}{*}{1066} & 0.819 \\
& Male & 286 & 62.17 & 8.35 & & & \\
\hline
\end{tabular}

Table 3: Significance of difference between mean scores of Nomophobic rate and Social media usage of higher secondary students in relation to their locality

\begin{tabular}{lllccccc} 
Variable & Gender & Locality & N & Mean & t & df & Sig. \\
Nomophobic rate & Female & Urban & 255 & 67.22 & 0.811 & \multirow{2}{*}{1066} & 0.438 \\
& Male & Rural & 813 & 67.98 & & & \\
Social media usage & Urban & 255 & 61.69 & 8.65 & 1.280 & \multirow{2}{*}{0666} & 0.197 \\
& Rural & 813 & 62.46 & 8.37 & & & \\
\hline
\end{tabular}


Table 4: Significance of difference between mean scores of Nomophobic rate and Social media usage of higher secondary students in relation to their school management

\begin{tabular}{|c|c|c|c|c|c|c|}
\hline & & Sum of Squares & df & Mean Square & $\mathbf{F}$ & Sig. \\
\hline \multirow[t]{3}{*}{ Nomophobic rate } & Between Groups & 1150.596 & 2 & 575.298 & $3 \cdot 532$ & $0.030^{*}$ \\
\hline & Within Groups & 173457.123 & 1065 & 162.871 & & \\
\hline & Total & 174607.718 & 1067 & & & \\
\hline \multirow[t]{3}{*}{ Social media usage } & Between Groups & 152.902 & 2 & 76.451 & 1.073 & 0.342 \\
\hline & Within Groups & 75872.614 & 1065 & 71.242 & & \\
\hline & Total & 76025.516 & 1067 & & & \\
\hline
\end{tabular}

${ }^{*} p<.05$.

Table 5: Multiple comparisons of mean scores of nomophobic rate among government, aided and unaided higher secondary school students

\begin{tabular}{|c|c|c|c|c|c|}
\hline \multicolumn{3}{|c|}{ School management } & Mean Difference & Std. Error & Sig. \\
\hline \multirow[t]{6}{*}{ LSD } & \multirow[t]{2}{*}{ Government } & Aided & $-1.69834^{*}$ & 0.84823 & 0.046 \\
\hline & & Unaided & $-4.03676^{*}$ & 1.76080 & 0.022 \\
\hline & \multirow[t]{2}{*}{ Aided } & Government & $1.69834^{*}$ & 0.84823 & 0.046 \\
\hline & & Unaided & -2.33842 & 1.69498 & 0.168 \\
\hline & \multirow[t]{2}{*}{ Unaided } & Government & $4.03676^{*}$ & 1.76080 & 0.022 \\
\hline & & Aided & 2.33842 & 1.69498 & 0.168 \\
\hline
\end{tabular}

${ }^{*} p<.05$.

Multiple comparisons of mean scores of nomophobic rate among government, aided and unaided higher secondary students are given in Table 5. The post hoc test result indicates that the difference in the mean scores of nomophobic rate of higher secondary students from government and aided schools as well as government and unaided schools significantly differ at 0.05 level. But there is no significant difference between higher secondary students from aided and unaided schools with respect to their mean score in nomophobic rate. It is depicted in figure 1 as a box plot.

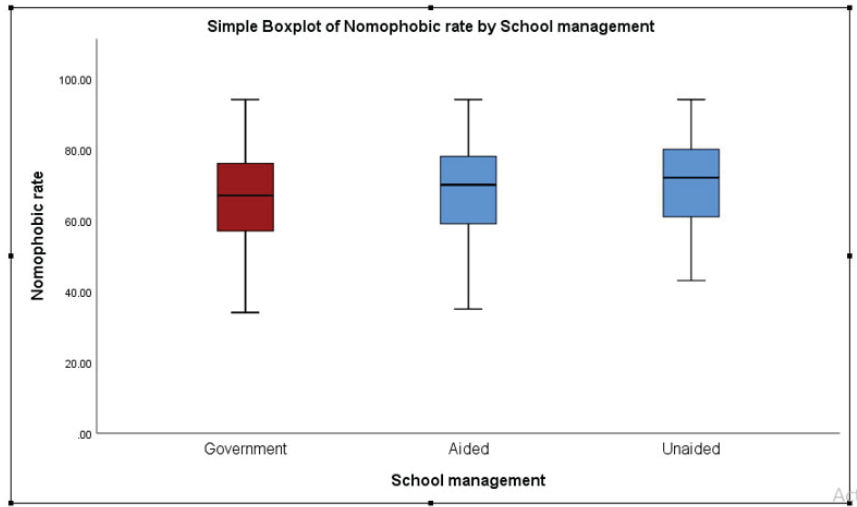

Figure 1: Mean scores of Nomophobic rate of higher secondary students from Government, Aided and Unaided schools.
A Pearson correlation of 0.4 is obtained when the correlation analysis between extent of social media usage and nomophobic rate among the higher secondary students were done. The value 0.4 indicates that the extent of social media usage and nomophobic rate are correlated moderately and the positive value shows that it is a positive correlation.

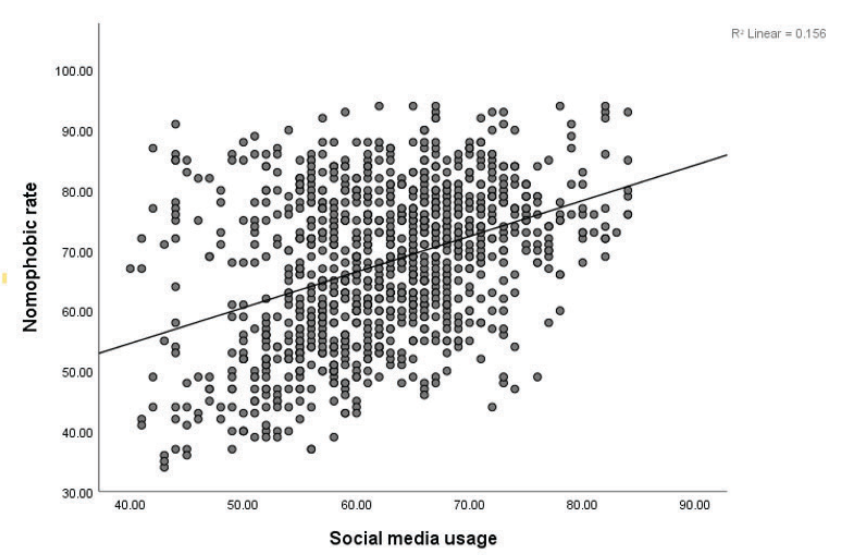

Figure 2: Scatter plot for correlation between social media usage and nomophobic rate of higher secondary students.

It reveals that the nomophobic rate among higher secondary school students would increase by 0.40 for every 
unit of standard deviation increase in social media usage among the students and this coefficient value is significant at 5\% level. It means that social media usage among the students will lead to a nomophobic tendency among them.

\section{RESULTS AND DISCUSSION}

The analysis of data revealed that male and female students, as well as students from the rural and urban areas, do not show any significant difference in their social media usage and nomophobic rate. But the ANOVA results of the study show that there is a significant difference between higher secondary students in relation to their school management. The post-hoc test revealed that the students from government schools significantly differ in their nomophobic rate with respect to that of aided and un-aided school students. But there is no significant difference between higher secondary students regarding their social media usage with respect to school management.

The correlation analysis show light on the fact that there is a positive correlation between social media usage and nomophobic rate. Even though the current study showed that the higher secondary students are not prevalent to nomophobia, they are prevalent in social media usage. As the correlation study reveals that social media usage is positively related to the nomophobic rate, it is notable to point out this result. These results go along with the findings of Usmani, S., Bhatti, K., Jindal, P., Bharti, A. \& Bharti, P. (2021) in some ways as well as that of the findings of Choksi, S. \& Patel, N. (2021). ${ }^{17,18}$

\section{CONCLUSION}

The role of parents in academic activities increased due to the pandemic situation. Parents and teachers at the higher secondary level as the second parents of students should take more care of the students because the learning process shifted to the online platforms. Usage of gadgets for academic purpose may lead to both nomophobia and higher social media usage. If prevalent social media usage or nomophobia is observed, the studies reveal that it is equivalent to some kind of addiction like tobacco and liquor.

\section{ACKNOWLEDGEMENT}

The authors would like to thank the authorities of the Department of Educational Technology Bharathidasan University, Tiruchirappalli and various school authorities who helped during data collection.

\section{Conflict of interest and source of Funding: Nil}

\section{Author Contributions}

Elias, Jijish designed and formulated research goals and objectives as a whole. After discussion with Mirunalini, $\mathrm{M}$ and Paul, Issac, determined the right method and designed the study model. Elias, Jijish prepared the tool and validated it with the help of Mirunalini, M and Paul, Issac. Data for the study was collected by Elias, Jijish and analyzed under the supervision of Mirunalini, $M$ and Paul, Issac and critically revised the manuscript and all authors had approved the final version.

\section{REFERENCES}

1. Aldahdouh. T. Z., Nokelainen. P., Korhonen. V.Technology and social media usage in higher education: The influence of individual Innovativeness. SAGE Open. 2020; 10(1), 215824401989944.

2. Kaplan A, Haenlein M. Users of the world, unite! The challenges and opportunities of Social Media. Bus Horiz. 2010;53(1):5968 .

3. Ellison N, Steinfield C, Lampe C. Satisfaction with MSU Life Scale. PsycTESTS Dataset. 2007;12(4):1143-1168.

4. Yildiz Durak H. What Would You Do Without Your Smartphone? Adolescents' Social Media Usage, Locus of Control, and Loneliness as a Predictor of Nomophobia. Addicta: The Turk J on Addictions. 2018;5(3):543-557.

5. Daei A, Ashrafi-Rizi H, Soleymani MR. Nomophobia and Health Hazards: Smartphone Use and Addiction Among University Students. Int J Prev Med.2019:10(1):202.

6. Jose M, Tomy L, Chesneau C. Impact of social media in academic performance and family relationships among college students. The Online J Distance Educ and e-Learn. 2021;9(1):106111.

7. Saini N, Sangwan G, Verma M, Kohli A, Kaur M, Lakshmi P. Effect of Social Networking Sites on the Quality of Life of College Students: A Cross-Sectional Study from a City in North India. The Sci World J. 2020;2020:1-8.

8. Tutgun Ünal A. A Comparative Study of Social Media Addiction Among Turkish and Korean University Students. J Eco Cul and Soc. 2020:307-322.

9. Barnes S, Pressey A, Scornavacca E. Mobile ubiquity: Understanding the relationship between cognitive absorption, smartphone addiction and social network services. Comput Human Behav. 2019;90:246-258.

10. Olmsted S, Xiao M. Factors affecting smartphone dependency of media consumers. Int J Mobile Comm. 2019;17(3):353.

11. Ayar D, Özalp Gerçeker G, Özdemir E, Bektaş M. The Effect of Problematic Internet Use, Social Appearance Anxiety, and Social Media Use on Nursing Students' Nomophobia Levels. CIN: Comput, Inform, Nur. 2018;36(12):589-595.

12. Yılmaz R, Karaoğlan Yılmaz F, Öztürk H, Karademir T. Examining secondary school students' safe computer and internet usage awareness: An example from Bartın province. Pegem Eğitim ve Ögretim Dergisi. 2017;7(1):83-114.

13. Salehan M, Negahban A. Social networking on smartphones: When mobile phones become addictive. Comput Human Behav. 2013;29(6):2632-2639.

14. Joy Paul G, Fundamental statistics in psychology and education. $2^{\text {nd }}$ ed. McGraw-Hill Companies; 1950.

15. Louis Edwards A. Techniques Of Attitude Scale Construction. 1st ed. Ardent Media; 1983. 
16. Jijish E, Mirunalini M. Nomophobic Rate of Higher Secondary Level Students - A Pilot Study. Int J Curr. 2021;13(19):85-89.

17. Usmani S, Bhatti K, Jindal P, Bharti A, Bharti P. The Effect of Internet Addiction on the Sleep Pattern and Quality of Life Among Medical Students. Int J Curr. 2021;13(03):159-164.
18. Choksi S, Patel N. A Study to Find Out the Correlation of Mobile Phone Addiction with Anxiety, Depression, Stress and Sleep Quality in the College Students of Surat City. Int J Curr. 2021;13(08):137-142. 